This article appeared as a contribution to a Forum on "The WTO after Cancún", in: INTERECONOMICS - Review of European Economic Policy, Volume 38, Number 5, September/October 2003, pp. 241-245.

\title{
The Challenge of Reforming the WTO Dispute Settlement Understanding
}

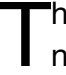
he May 2003 deadline for the completion of the negotiations on improvements and clarifications of the Dispute Settlement Understanding (DSU) under the Doha Mandate has not been met. However, Members agreed in July 2003 to extend the deadline for the review until the end of May 2004. This article briefly summarises the past six years of negotiations on the DSU review, the most contentious issues and the systemic difficulties of the negotiations. We conclude with prospects for the forthcoming negotiations until 2004.
\end{abstract}

\section{The DSU: Rules for Settling Disputes in the WTO}

The DSU contains the rules for settling disputes between WTO Members that arise under the agreements covered. In short, it provides for a procedure that starts with mandatory consultations as a negotiatory element. If the parties cannot agree to a settlement during these consultations within a certain period, the complainant may request a panel to review the matter. Panels engage in fact-finding and apply the relevant WTO provisions. Their findings and recommendations are published in a report, which either or both of the parties may appeal. The Appellate Body is then to review the issues of law and legal interpretations in the panel report. It can uphold, modify or reverse the panel's findings. Subsequently, the reports are adopted in a quasi-automatic adoption procedure by the Dispute Settlement Body (DSB) where all WTO Members are represented by a delegate. "Quasi-au-

\footnotetext{
* Professor of international economics and director of the Swiss Institute for International Economics and Applied Economic Research, University of St. Gallen, Switzerland (http://www.siaw.unisg.ch).

${ }^{* * *}$ Research Associate, Swiss Institute for International Economics and Applied Economic Research, University of St. Gallen, Switzerland.
}

Intereconomics, September/October 2003 tomatic" adoption means that the reports are adopted unless the parties decide by consensus (i.e. including the party that has prevailed) not to adopt the report. If it has been found that a trade measure is in violation of WTO law, the defendant must bring this measure into compliance with the covered agreements within a reasonable period of time, normally not exceeding 15 months. If the defendant refuses to comply, the complainant may ask the defendant to enter into negotiations on compensation, or it may seek authorisation from the DSB to suspend concessions or other obligations vis-à-vis the defendant in an amount equivalent to the injury suffered. If the adequacy of implementation is disputed, the implementation measures are subject to further review under the DSU. Retaliation, if authorised, normally takes the form of punitive tariffs on a defined volume of the complainant's imports from the defendant.

The DSU has often been praised as the "crown jewel" of the Uruguay Round Agreements. Key innovations with regard to dispute settlement under the GATT are strict time-frames and the lifting of the former consensus requirement which allowed a defendant to block the adoption of an adverse ruling. Since the DSU entered into force on 1 January 1995, its provisions have been applied to the settlement of some 300 disputes on a wide range of topics.

\section{DSU Review: Fruitless Efforts Since 1998}

Originally, a 1994 Ministerial Decision had called upon Members to complete a full review of the DSU by 1 January 1999, and to take a decision whether to continue, modify, or terminate the DSU at the Seattle Ministerial Conference. Despite intense discussions and an extension of the deadline until July 1999, no 
result was achieved. After the failure of the Seattle Ministerial in December 1999, the DSU review fell into an inconclusive limbo. Efforts to further the review during 2000 and 2001 remained unsuccessful. It was only at the Doha Ministerial Conference in November 2001 that a mandate for further negotiations on improvements and clarifications of the DSU was included in the Ministerial Declaration. Between spring 2002 and May 2003, 42 specific proposals were submitted by members, covering virtually all provisions of the DSU. The "Chairman's text" of 28 May 2003, named after the Chairman of the negotiations Péter Balás, incorporates many of these proposals and was meant to serve as a basis for agreement. ${ }^{1}$ However, portions of the text are still bracketed (which indicates disagreement between the parties) and, more important, many of the more controversial proposals have been left out. Although the text was not accepted by the negotiators, it is worth looking at in some detail.

\section{Searching for Compromise: The Balás Text}

The Balás text contains a procedure to overcome the "sequencing issue" which arose over ambiguities (or even contradictions, as some may argue) in Art. 21.5/22 DSU. It surfaced during the EC - Bananas case, where the WTO-consistency of the EU implementation measures was disputed. The key question is whether a "compliance panel" must first review the implementation measures undertaken by a defendant before a complainant may seek authorisation to retaliate on grounds of the defendant's alleged non-compliance. Whereas the US initially opposed any idea of sequencing and favoured immediate retaliation, the EU and many other Members argued in favour of the completion of such a compliance panel procedure as a prerequisite to seeking an authorisation to retaliate. Over time, however, this debate lost its acrimony: after the US had been defeated in the US - Foreign Sales Corporations (FSC) case, it found itself unable to implement the rulings in a timely and WTO-consistent manner. It subsequently agreed with the EU on sequencing for that particular case. This practice, which was also applied in other disputes, would now have been introduced into the DSU.

The Balás text would also have brought noteworthy modifications at the appellate stage, introducing an interim review, and a remand procedure. In this procedure, an issue may be remanded to the original panel in case the Appellate Body is not able to fully address an issue due to a lack of factual information in the panel report. Remand panel reports could be appealed

${ }^{1}$ Document TN/DS/9, available at the WTO website. as well. The compromise text would have introduced numerous amendments in other areas, including, inter alia, housekeeping proposals, enhanced third party rights, enhanced compensation, strengthened notification requirements for bilateral solutions, and special and differential treatment of developing countries.

\section{Contentious Issues}

The controversial issues that have not been integrated into the text include, for instance, several elements of a proposal by the United States and Chile on "improving flexibility and member control in WTO dispute settlement". Obviously motivated by a series of defeats in trade remedy cases and a surge of criticism of WTO dispute settlement from US Congress, it would have allowed the deletion of findings in panel or Appellate Body reports by mutual agreement of the parties. Furthermore, it would have provided for the partial adoption of panel and Appellate Body reports, and it called for "some form of additional guidance to WTO adjudicative bodies". A majority of small and medium-sized trading nations refuses any increase of political control, as this would automatically benefit the more powerful Members.

Another proposal that was not taken into account is the EU call for a permanent panel body. Whereas panelists are usually government officials or other trade specialists who are appointed ad hoc and discharge their tasks as panelists on a part-time basis and in addition to their ordinary duties, the EU wants to establish a roster of 15 to 24 full-time panelists. The EU hopes that this would lead to a professionalisation of the panel process and help overcome problems with the selection of panelists, as parties find it increasingly difficult to agree on the composition of panels. Opponents of the proposal argue that members of a permanent panel body could be more "ideological" and might engage in lawmaking. They therefore feel more comfortable with the current system as it draws heavily on government officials who are familiar with the constraints faced by governments. The EU equally failed in introducing a prohibition on "carousel" retaliation. Carousel retaliation consists of periodic modifications of the list of products that are subject to the suspension of concessions if a respondent fails to comply with an adverse ruling. The US signed such provisions into law in 2000 as the EU did not comply with the adverse WTO rulings in the Hormones and Bananas cases. Although the provisions have never been applied, the EC continues to oppose them as it already did in the DSU review during 1999.

Intereconomics, September/October 2003 
The US, in turn, failed to have its proposals on increased transparency considered. The US wants to make submissions of parties to panels and the Appellate Body public, and it wants to allow public observance of panel and Appellate Body meetings. Particularly developing countries oppose such increased transparency, as they fear "trials by media" and undue public pressure. Insisting on the intergovernmental nature of the WTO, they also resist efforts by the US and the EC to formalise the acceptance of amicus curiae or "friend of the court" briefs. Amicus briefs are unsolicited reports which a private person or entity submits to the adjudicative bodies in order to assist (and to influence) the Court in its decision-making. The issue had surfaced for the first time in 1998 when the Appellate Body decided in US - Shrimp/Turtle that the panel had the authority to accept unsolicited amicus curiae briefs. That right was subsequently expanded in further disputes, causing outrage among many developing country Members.

Developing countries, in turn, did not manage to introduce collective retaliation into the draft. It was meant to address the problems caused by the lack of retaliatory power of many small developing economies, such as those experienced by Ecuador in the EC - Bananas case. With collective retaliation, all WTO Members would be authorised (or even obliged under the idea of collective responsibility) to suspend concessions vis-à-vis a non-complying Member.

\section{Diverging Views on the Fundamental Orientation of the DSU}

There are at least three major reasons why it has been so difficult to agree on a compromise text. The first one is disagreement on specific issues as outlined above, combined with a lack of political will to settle for a compromise. The second one is a more fundamental disagreement which blocks successful negotiations: the dispute settlement system has gradually moved, over the past few decades, from barely codified practices relying heavily on diplomatic negotiations to an increasingly codified litigation mechanism with strong emphasis on the rule of law. Currently, however, there seems to be no consensus on whether that trend towards judicialisation should continue. Some proposals would contribute directly or indirectly to a strengthening of the rule of law, such as a professional permanent panel body, increased notification requirements for mutually agreed solutions, improved enforcement or strengthened third party rights. Other submissions, however, such as the US proposal on flexibility and increased Member control, aim at reversing this trend and seek to strengthen the political element of dispute Intereconomics, September/October 2003 settlement. While one might expect at first that this is largely an issue that divides larger and smaller nations, things are not as simple as that: many developing countries equally argue for strengthening the negotiating mechanisms, as they are disappointed with the final outcome of litigation. The Ecuadorian experience in the Bananas case has shown that retaliation as the last resort is ineffective for small developing countries. Not only do they lack retaliatory power because of insufficient market size, but they would also mainly harm their own development prospects by shutting out imports from industrial nations. Moreover, litigation is expensive. Finally, overall political considerations (such as GSP preferences, official development assistance and many others) may prevent developing countries from engaging in litigation with developed countries.

\section{Systemic Difficulties in Reforming the DSU}

Thirdly, there are also systemic reasons for the low success of the DSU review: the dispute settlement mechanism has a "constitutional" character, as it contains the basic rules for the settlement of any dispute that may arise under any of the covered WTO Agreements. Factually, it also has a crucial function in interpreting the provisions. Not surprisingly, the decision to approve amendments to the DSU shall be made by consensus, as Art. X.8 WTO Agreement provides. As Rawls taught us, constitutional rules should always be agreed by actors in the "original position" and behind a "veil of ignorance" in order to prevent self-serving choices. In the reality of trade policy, however, such a veil of ignorance does not exist, as Members, after nearly 300 disputes, know fairly well their own and the other parties' vulnerabilities. The "context" in which the DSU review takes place thus creates difficulties on three levels in particular.

- Firstly, the review is conducted in the light of the substance of the disputes that are brought to the WTO on a continuing basis, and in particular of the politically more controversial ones. It is in these disputes or in their respective context where all the crucial issues in the debate have arisen (sequencing and collective retaliation in Bananas, carousel in Hormones, and amicus curiae in Shrimp/Turtle) and where country positions have been shaped. In addition, country positions are not only influenced by past experience but also by expectations with regard to looming disputes. For instance, the EC will have been aware during the entire review exercise of a potential challenge to its GMO regime. Indeed, a panel has now been established. 
- A second element of this context consists of specific procedural disagreements which, at the same time, are the subject both of on-going disputes and of negotiations on the DSU. For instance, the EC tried to settle the sequencing dispute by making it the subject of specific complaints in US - Certain EC products and US - Section 301. Similarly, a consultation request in US - Section 306 on carousel retaliation is still pending. Each time such a dispute is under consideration and the outcome is unclear, no party has an interest in prejudicing its position through a prior agreement on the issue during DSU review negotiations.

- Finally, the third layer of this context consists of ongoing negotiations on material WTO law. The extent to which new disciplines such as the Singapore issues (e.g. investment, competition) could be subject to dispute settlement rules has a direct impact on Members' approach to the DSU. This logic also holds for the re-negotiation of existing agreements. For instance, there is a clear link between the current Doha Round negotiations on WTO Rules (such as anti-dumping and countervailing measures) and the on-going US debate on the "standards of review" applied by the adjudicative bodies. It will clearly be more difficult for the US to agree on new rules on trade remedies in a setting where the adjudicative bodies act independently than if they operate under close control of Members.

Add to these considerations a dynamic aspect: this entire context is not static, but it evolves with each new (or merely expected) development that threatens to modify positions taken on the DSU review, thereby making negotiations even more difficult.

\section{What Can We Expect from Negotiations Until the New May 2004 Deadline?}

The foregoing analysis may help us to evaluate the context under which the review will take place during the following months as the new May 2004 deadline comes closer.

As far as potential outcomes are concerned, fundamental changes to the system must not be expected. Each of the more far-reaching proposals with implications on the fundamental orientation of the DSU (rule versus power-orientation) will not be acceptable to a substantial number of Members. Therefore, a package of mainly technical modifications seems to be feasible at best. Such a package, however, may not enjoy sufficient support from the large players (notably the EC and the US) as it will do little to satisfy their ambitions and improve their situation.
Although the EC and the US are not the only participants in the negotiations, much will depend on the evolution in (and between) Brussels and Washington. Figures available today suggest that the US will continue to be in a defensive position, because (as of 22 July 2003) it was the complainant in only 10 active cases, as opposed to 21 active cases where it was the defendant. Of the latter, all but two concern trade remedies. ${ }^{2}$ More adverse rulings will therefore likely spur the criticism of Congress and prevent US negotiators from consenting to any package that would not increase political control. Interests could change, however, if the US prevailed in the new transatlantic trade dispute on Genetically Modified Organisms (GMOs). Rulings in the GMO case could finally set the stage for a comprehensive settlement of all outstanding transatlantic trade disputes within a package. So far, the EU has consistently refused any package deal, probably because not all issues were on the table. If accounts could finally be settled, pressure from DSU negotiations could be lifted and a mini-package might become feasible. However, settling the many cases involving the US would not only have to involve the EC but many other important WTO Members such as Japan, China, India or Brazil.

As this is a tremendous task, it is unlikely that the new May 2004 deadline for the DSU negotiations will be met - particularly now that the failure of the Cancún Ministerial has caused a severe setback to the Doha Round negotiations in general.

A lack of progress on the DSU review does not, however, need to impair the functioning of the DSU. First of all, negotiators have missed several deadlines so far, and the DSU is still functioning relatively well. Secondly, provisional solutions have been found for most practical problems in DSU practice: For instance, countries make bilateral agreements on sequencing that bridge the gaps of Articles 21.5/22. With regard to the amicus issue, the Appellate Body has developed its own methodology which grants a lot of discretion. It is using this discretion wisely, displaying a general openness towards accepting amicus briefs while at the same time not giving them decisive weight in its decisions, at least not explicitly. And as some observers privately argue, the increasing judicial restraint which the Appellate Body exercises in trade remedy cases helps to appease growing US concerns with regard to an alleged anti-US bias of the system. These are just three examples which show that the system

2 USTR: Snapshot of WTO Cases Involving the United States, updated 22 July 2003; http://www.ustr.gov/enforcement/snapshot.pdf.

Intereconomics, September/October 2003 
has displayed enough flexibility to deal with new issues as they arise.

Whereas the timely completion of the DSU review is therefore less urgent, the improvement of the political decision-making mechanism will be crucial. Adjudicative bodies are currently forced to issue rulings even on provisions that have been left deliberately vague as negotiators were unable to agree on clear treaty text. Interpreting these vague provisions in a legal adjudication procedure inevitably creates political tensions. These, however, are difficult to correct as the political decision-making mechanism in the WTO is very weak. This imbalance between the inefficient political decision-making mechanism and the efficient adjudication mechanism causes problems for the long-term sustainability of the WTO. Whereas the US proposal seeks to remedy the imbalance by introducing more political elements into the dispute settlement procedure, legal scholars strongly advocate an improvement of political decision-making. Changing the traditionally consensus-based decision-making in the WTO, however, is yet a much more formidable task than the relatively limited DSU review. 